\title{
旧醸造試験所酒類醸造工場の四面書入れ寸法と煉瓦モデュール \\ DIMENSIONAL STUDY ON BRICK MASONRY BREWERY BELONGED TO NATIONAL RESEARCH INSTITUTE OF BREWING
}

\author{
長谷川 直司*, 馬 場 明生**, 守 明 子*** \\ Naoji HASEGAWA, Akio BABA and Akiko MORI.
}

\begin{abstract}
This paper deals with the measure planning of a clay brick masonry brewery designed by Yorinaka TSUMAKI build in 1903, on the basis of documents possessed by the institute and the survey on site. The results are as follows. The measure entered in the drawing paper was abnormally so much detailed, because of the modular size of masonry units was considered only in the thickness of brick walls. On the other hand, the modular coordination was not considered concerning the sizes of rooms. A detailed adjustment technique was adopted in the stage of construction. On the same wall, modular size of masonry units was very rare to be altered into an irregular size.
\end{abstract}

\author{
Keywords : Brick masonry building, Modular size, Meiji era, Brewer, YorinakaTSUMAKI \\ 棟瓦造、モデュール寸法、明治期、蠤造工場、妻木頼黄
}

\section{1. はじめに}

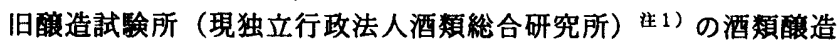
工場は、都内に現存する明治期の赤棟瓦建築物である（写真 -1 )。 これまで調查、研究の対象として取上げられたことが少なく壮2)、そ の建築史的、技術史的評価も定まっていないが、都内に現存するこ と、建築設計・工事監督に妻木頼黄が関与していること、建設後 100 年を経過した今日においても基本的に当初用途に活用されているこ と、創建時の努からの改変が少ないこと、などにより貴重な歴史的 建造物および近代化遺産の可能性が高いと考えられる。

また、組轿設立当初 (明治 37 年(1904)5 月から明治 44 年(1911)4 月）の資料を綴じた「官有財産書類／酮造試験所」が保存されてい る。このなかには、施設整備と国有財産管理を担当する大藏大臣官

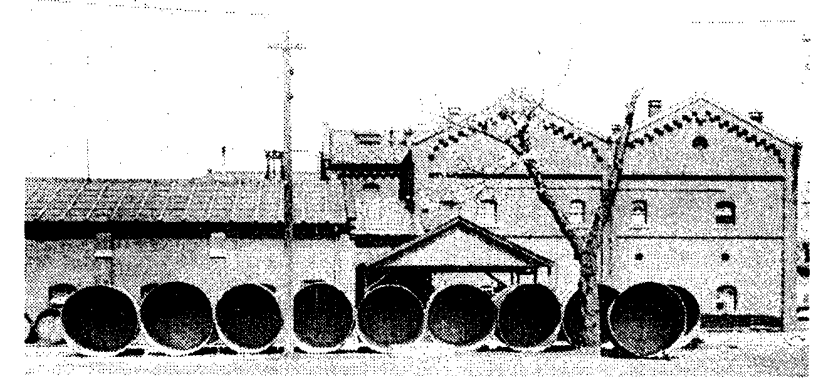

写真 -1 酒類酸造工場（南面：B 構面 $\cdot F$ 構面） 出典：刢立二十五周年琼念鍮菜書 昭和 4 年(1929)
房営繥課の報告と酸造試験所からの財産增隇異動報告等の往復公文 書が経られており、建築図面も部分的に含まれている。

本稿は、酒類醇造工場の建設経緯の概要に触れたあと、棟瓦壁体 の構工法に着目し、残されている図面と現地の調查から、特に部材 寸法の决定経緯について、設計寸法と、棟瓦モデュールを配虑した 生産寸法の関係を明らかにし、明治後期の煉瓦造建築物の生産技術 の一端を解明しようとするものである。

\section{2. 建設および復旧の経椲と妻木頼黄の関与}

酒類総合研究所は 2004 年 5 月 9 日には創立 100 周年を迎える。 この日程の起算となった明治 37 年 (1904) 5 月 9 日は、大藏省醅造試 験所の官制交付の日付である ${ }^{\text {住 } 3)}$ 。しかし、組織設置の検討や施設 整備はこれに先行している。以下その概要を「醕造試験所沿革誌」1) (以下、沿革誌) と「酮造試験所七十年史」 2)（以下、70 年史）か ら引用して示す。

• 明治34年(1901)7月 農商務省、大藏省合議により、日本酒醇造改 良実験及講習所設置調查委員を嘱託。

・明治34年(1901)8月 調查委員報告。ここで名称は醇造試験所、設 置場所は東京、管轄は農商務省、などが提案される。これを受けて 醇造試験所設立の政府决定。帝国議会への案の提出。その協賛によ り明治35～36年 (1902 1903) 度予算決定。 •明治35年(1902)4月5日 設立事務取扱所を農商務省商工局に設置。 敷地を探す。現在の滝野川以外に6籄所の候補地があった。
* 国土交通省国土技術政策総合研究所 室長・工修

** 山口大学工学部感性デザイン工学科 教授・工博

*** 名古屋工業大学大学院工学研究科つくり領域 教授・博士(工学)
Head, National Institute for Land and Infrastructure Management, MLIT, M. Eng. Prof., Department of Perceptual Sciences and Design Engineering, Faculty of Engineering, Yamaguchi Univ., Dr. Eng.

Prof., Tsukuri College, Graduate School of Engineering, Nagoya Institute of Technology, Dr. Eng. 
・明治35年 (1902)8月に䋯地を印刷局用地であった滝野川に決定。 ・明治35年 (1902)10月 13日 敷地と旧建物4棟を印刷局より授受。 そして予算に従って明治 35 年度と 36 年度で酒類醇造工場を含め 施設整備が実施されたが、敷地決定に日時が費やされ、35年度の半 年ほど過ぎたころの決定であったので、35年度は酒類醇造工場の新 築のみに計画変更した。しかも複雑な設計が必要とされ時間がかか るので、事務取扱所設置の直後から數地未定のまま設計が進められ、 敷地決定時にはほほ設計を済ませ、すぐに請負工事に出した。

その他の事務所や研究所等の建物は明治 36 年 (1903) 度にまとめ て建設した。機械類の設置は37年(1904)度までずれ迈んだ。

浻革誌と70年史の記述の引用元の文書が、「明治三十六年末マデ /設立準備中ノ重要文書」綴りとして保存されている。この綴りの なかの明治35年 (1902) 12月6日付け、農商務省商工局長発「酸造試験 所新筑ノ件」で請負工事は大倉土木組、清水満之助、宮崎善吉、長 谷川金太郎の4者の指名競争入札に付すべく伺いが出ている。そして 宮崎善吉が落札し工事を担当している壮4)。また、酒類酹造工場の施 工工期は明治 36 年 (1903) 2月1日起工、竣工は当初同年11月 7 日とさ れていたが、基礎工の設計変更により11月30日竣工の記録がある注5)。 この間、

•明治36年 (1903)10月1日 醇造試験所の管轄は農商務省から大藏省 へ変更する旨、両大臣連名で閣議決定を求める。

・明治36年 (1903) 10月3日 前記旨閣議决定。

・明治36年(1903)10月31日 大藏省に設立準備委員会設置。

•明治36年(1903)11月2日 農商務省から大藏省へ醇造試験所所属の 建築物その他一切を引き継ぐ。

そしてこの経緯ののち、明治37年(1904)5月9日の官制交付になる。 その後、大正 12 年 (1923) 9 月 1 日の関東大震災の際は、敷地内の 他の施設には大きな被害が出ており記録されているが ${ }^{3)}$ 酒類醅造工 場にはその記録がなく、ほとんど被害は無かったものと考えられる。

しかし 70 年史によると、昭和 20 年(1945)4 月 13 日夜半に太平 洋戦争の空襲を受け瓦茸き屋根を焼失し、その後昭和 22 年(1947)3 月に亜鉛鉄板瓦棒茸きとして復旧し4）今日にいたっている。

その他、2 階煉瓦妻壁が積み直され外钼がモルタル塗りになって いる部分があるが、これがいつの復旧工事であるかは分からない。

さて、妻木頼黄の関与であるが、上記明治 35 年 (1902) 4 月 5 日の 農商務省商工局に設置の設立事務取扱所において設立事務取扱のう ち「建築設計及監督嘱託」として名を連旼ている。局書きは「大藏 技師工学博士」である。また特に敷地選定委員のひとりにも命じら れていて、候補地全ての実地踏查に参加している ${ }^{5)}$ 。

酒類酮造工場の設計については、治革誌によると ${ }^{6)}$ 、「妻木大藏 技師其他酸造技術者ヨシテ本邦清酒工場ノ設備卜独国麦酒醅造会社 ノ建築法ヨ勘酷セシ义設定シタルモノニシテ、其計画八本邦創始ノ 事業ニ属シ」とあり、妻杖設計関与を明記している生 8)。

また、妻木頼黄経歴とされる文書中に「政府カ始メテ醇造試験所 ヨ新設セラルル二際シ其新営計画ノ任二腐リ四季醅造二通スル新案 設備 ヨ為セリ」の文言がある注 ク。

この時期の妻木頼黄の大藏省における位置は、明治 29 年 (1896) 10 月臨時葉煙草取扱所建築部技師建築掛長、明治 33 年 (1900) 2 月臨時 税関工事部技師建筑課長、明治 37 年 (1904) 4 月臨時煙草製造準備局 技師、明治 38 (1905) 年 10 月大藏省臨時建築部技師部長といった「臨
時」の機構の建築部門の長にある。それらの職と併任で営繥課の課 長職にもあった ${ }^{7)}$ 。営繥課は明治 35 年 (1902)までは総務局にあっ たが 36 年 (1903) 以降は大臣官房に属している。設立事務取扱に「大 蔵技師」とあるように、醇造試験所の建設に関与する祭の局書きと しては「営結課長」であった。なお、明治 35(1902) 年度における営 䋨課の陣容は、妻木課長のほか建築職では、臨時税関工事部技師兼 任の矢橋賢吉、同技手兼任の原虎之助、技手の沼尻政太朗、松井鎌 五郎が(る ${ }^{8)}$ 。

\section{3.「官有財産書類」の内容}

書類経りは表紙に官有財産書類、酾造試験所と畦書され、第壱号、 永久保存の印が打たれている。内容はまず、明治 37 年(1904)5 月 12 日付け文書番号「営第 251 号」の官有財産目録引継書である。 発行は大藏省大臣官房営絴課長妻木頼黄とあり公印付きである。送 り先は醇造試験所長目賀田種太郎である。続いて目録の本体が掲載 され、「土地及附属物ノ部」「営造物及附属物ノ部」「家屋及附属物ノ 部」がリスト化されている。

酒類醇造工場は、「営造物及附属物ノ部」のなかで、「所在地：東 京府豊島郡滝野川村大字滝野川字逆サ川、営造物：硫造工場、建物 構造種 : 棟瓦造木造、建物番号 : 二、数量 : 三四四、九五三（二階） 一一五、三一八 (三階) 二○、九六○、価格：六五、二一一，四一 九、增年月：明治三十七年四月、記事：平家坪ノ内六六、二九○八 木造」とある。リストにはその他主なものに、事務所 (木造)、略式 醇造工場 (木造)、研究所 (棟瓦造)、倉庫 (棟瓦造)、寄宿含 (木造) などが記載されている。

リストに続いて、各営造物、家屋の略平面図、施設配㯰図、敷地 内設備配線図が揭載されている。明治末年頃からは油場の新築、 略式醇造工場の用途替えにより、当該工場は酒類酸造工場と呼称さ れ今日に至っているので本稿ではこの名称を採用する。

書類緅りはこの冒頭の「引継目録」につづき、若干の追加引継ぎ が大蔵大臣官房営絴課発で出ているが、緅りのその後のほとんどは、 醇造試験所長からの定期的な官有財産增隇異動報告の提出伺い起案 文書である。年に 4 回の報告義務があったとみられる。明治 37 年 (1904) 10 月 28 日付けの「明治 37 年度第 2 期家屋及附属物增減異 動報告」から明治 44 年(1911) 4 月 14 日付け「明治 43 年度第 4 期 官有財産增減異動報告」の起案文が 26 通緅られている。それらの 送り先は全て大藏大臣官房営縒課長工学博士妻木頼黄であり、国有 財産を管理する営繥課に対する報告となっている。これらのなかで、 酒頪醇造工場の図面が添付されているのは、明治 39(1906)年 1 月 29 日付けの明治 38 年度第 3 期分の報告の「通風装置略図」に部分 断面図と部分平面図が、明治 40 年(1907) 1 月 15 日付けの明治 39 年度第 3 期分の報告の「電燈配置図」に詳細な平面図がある。

\section{4. 酒類酸造工場の図面に書入れられた寸法の考察}

寸法の書入れられた図面は、明治 37 年(1904)5 月 12 日付け引継 目録添付の平面図（以下、略平面図という）と明治 40 年(1907)1 月 15 日付け文書添付の電燈配置図 (以下、詳細平面図という)である。 電燈配置図の目的は新規に取りつけた電燈の配置を示すものである か、この図面は建築設計用に作成された平面図を下敷きにして作成 されており、もとの平面図が失われている今日、これを詳細な平面 


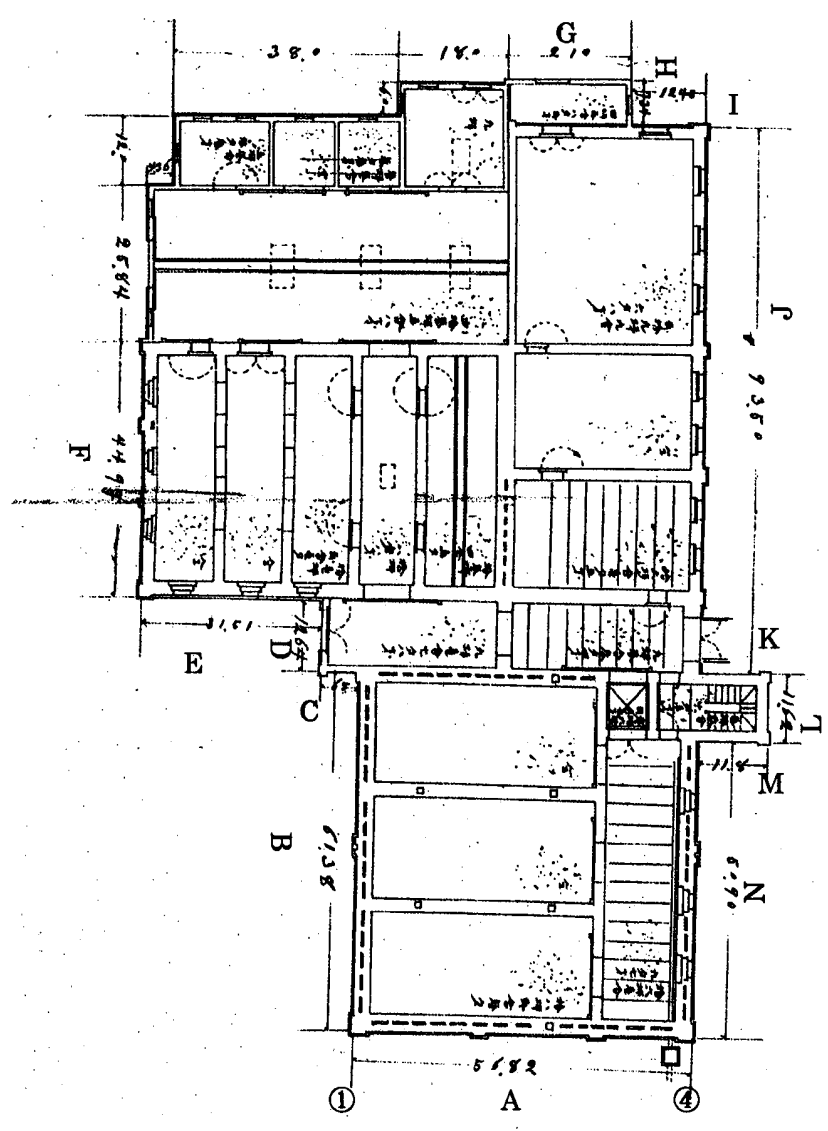

図一1 1 階略平面図

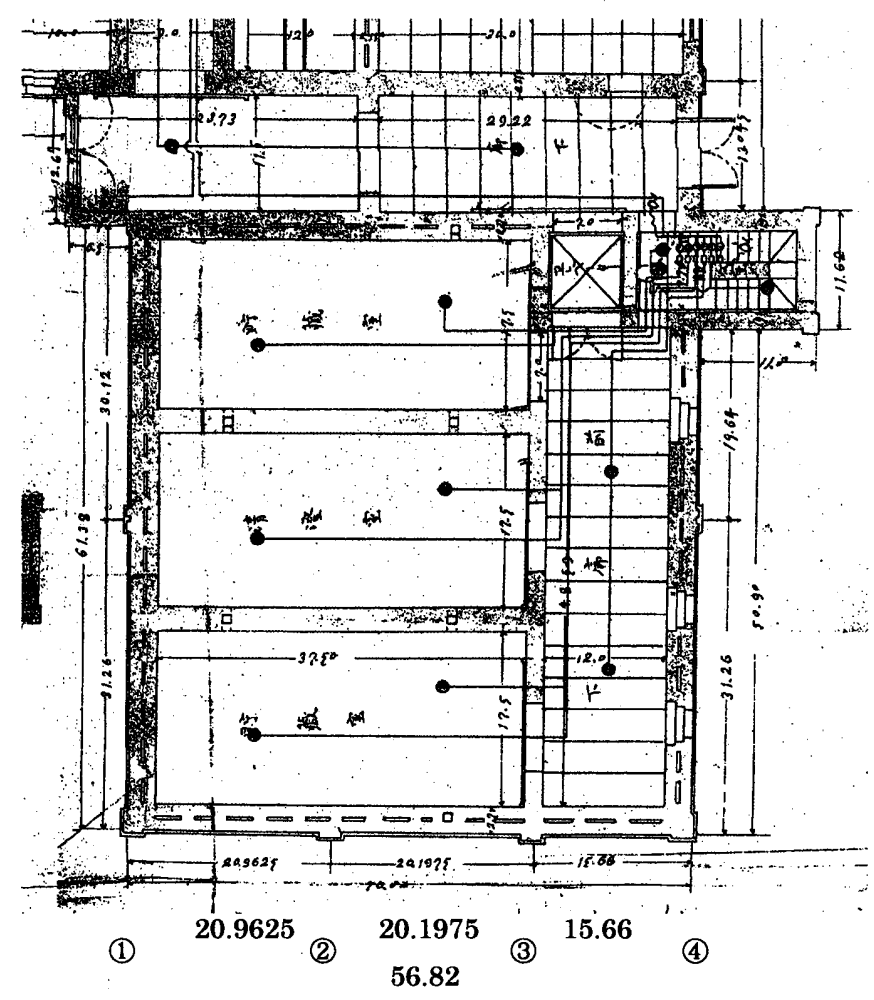

図-2 1 階詳細平面図（部分）
図として扱い、检討の対象とする。

酒頼酸造工場の外壁面は平面図上、出腢、入隅が多く便宜上、構 面ごとに A から N の名称をつける（図-1）。略平面図に書入れさ れた寸法は、A 構面が 56.82、B 構面が 61.38 などとなっており、 これはそれぞれ 56 尺 8 寸 2 分、61 尺 3 寸 8 分を示している。つま り「分」の位まで記述しているがこれは 1 分が約 $3 \mathrm{~mm}$ であることを 考えると、建築图面の記入寸法としては異常に細かい思われる。さ らに詳細平面図の $\mathrm{A}$ 構面への記入寸法は、20尺 9 寸 6 分 2 厘 5 毛、 20 尺 1 寸 9 分 7 厘 5 毛などとあり、「毛」の位（ただし 5 毛ビッチ にまるめてはいる）まであり、 5 毛が約 $0.15 \mathrm{~mm}$ であることを考えれ ば実現不可能な寸法精度要求であるといえる(図-2)。

一方、同敷地内の木造建築物の略平面図への記入寸法は、「尺」 の位でおおむね納めており、ときどき 5 寸の位がある程度である。 そうすると「分」の位やさらに「毛」の位まで書入れる意味は煉瓦 造であることとの関係が推測される。他の煉瓦造建筑物である研究 所や倉庫の略平面困にも「分」の位まで書入れられている。

平面詳細図には、室の内法寸法や煉瓦壁厚が記入されている。壁 厚に着目すると $\mathrm{A}$ 構面 1 階が「2.7」、 $\mathrm{F}$ 構面が「2.31」、 $\mathrm{K} 、 \mathrm{M}$ 構面、 $\mathrm{D}$ 構面 2 階が「1.92」と齐める。その他内壁にも $2.31 、 1.92 、 1.53$ といった值の書入れが見える。

娻瓦壁厚は一般に娻瓦の長手が何枚といった呼び方をする 9)。た だしそれは煉瓦単体の寸法だけで決定されるものではなく、綎目地 幅寸法との組み合わせとなる。

ここで娻瓦単体の長手寸法を L、縦目地幅を $\mathrm{jv}$ とすると、

壁厚 $=\mathrm{n}(\mathrm{L}+\mathrm{jv})-\mathrm{jv}$

となる。 $\mathrm{n}$ は長手枚数である。

明治 30 年代の娻瓦寸法については、大高庄右衛門の論文 ${ }^{10) か ゙ よ ~}$ く引き合いに出され、それによるといわゅる東京形と呼ばれるもの が普及していたという。東京形は、長手 $\times$ 小口 $\times$ 厚が 7.5 寸 $\times 3.6$ 寸 $\times 2$ 寸である。縦目地幅については、当時の建築技術書や仕様 書例によるとおおむね 2 分 5 厘から 3 分とされており、多くは 3 分（0.3 寸）を指定している年8)。上式にこの値を仮に入れると、

壁厚 $=\mathrm{n}(7.5+0.3)-0.3=7.8 \mathrm{n}-0.3$ となる。

これをもとに、例えば長手 3 枚半積み壁（ $\mathrm{n}=3.5 ）$ とすると、 壁厚 27 寸、同様に 3 枚積み壁は 23 寸 1 分、 2 枚半積み壁は 19 寸 2 分、 2 枚積み壁は 15 寸 3 分となり、詳細平面図に書入れさ れた壁厚の值と一致する。このことにより、酒類醇造工場の寸法 計画は、少なくとも壁厚に関しては東京形媡瓦の長手幅、小口幅 と縦目地幅 3 分の組み合わせで計画されていたことが判明する。

次に室の内法寸法に着目すると、A 構面に接する眝蔵室と前郎 下について、A 構面方向にそれぞれ 37 尺 5 寸、 12 尺と読める。 この值は合理的なものと考えられる。これに $\mathrm{B}$ 構面、N 構面それ ぞれ 1 階の壁厚である 2 尺 7 寸と貯藏室と前廊下を隔てる内壁厚 (これには寸法書入れがなく、他の壁との比較により 2 枚半積み 壁と推定した）の 1 尺 9 寸 2 分を総計すると、 56 尺 8 寸 2 分と なり、A 構面に書入れされた值 (A 構面の両端柱型の外々寸法で はなく、B構面の外面から $\mathrm{N}$ 構面の外面までの寸法)と一致する。

また、貯藏室内法寸法の長手方向が 37 尺 5 寸で短手方向が 17 尺 5 寸と“きりのよい值”であるのに対してその直上の室である 酶醉室はそれぞれ 37 尺 8 寸 9 分、 17 尺 8 寸 9 分となるのは、 $\mathrm{A}$ 
構面、B 構面の 2 階壁厚が 3 枚積み壁に絞られて、1 階の 3 枚半積 み壁より 3 寸 9 分薄くなった分、室内法寸法が增加したと考えれば 説明がつく。

以上のこと、およびその他の室の内法寸法と外壁構面の書入れ寸 法の検討から、次のことが言える。つまり、設計寸法の決定順位は まず 1 階の主要室（醅醉室、製水室、汽午室、前廊下等）の内法寸 法を“きりのよい值”（0.5 尺ピッチ）で決定し、他の室や上階の室 は内壁厚の増減や上階外壁厚の減を反映した值とする。外壁の書入 れ寸法に現れた「分」の位までの值は、“きりのよい”室内法寸法と 「分」の位まで考虑した壁厚の和として决定されたものと考えられ る。

次に、詳細平面図の A 構面に書入れされた「毛」の位の值につい て考察する。

まず、(3)軸(4)軸間の 15 尺 6 寸 6 分については、N 構面 1 階壁厚 2 尺 7 寸、前廊下幅 12 尺、貯藏室と前榔下を隔てる内壁厚の中心線 とする 9 寸 6 分（=1 尺 9 寸 2 分/2）の值の和と一致する。この ことよりこの内壁の厚が 2 枚半で計画されていたことも分かる。ま たこの壁を受ける、A 構面に設置された柱型の幅も2.5 枚厚であっ たと推定する (実施は 3 枚厚)。A 構面両端の柱型は 3 枚厚で計画 されたと推定し、左端の柱型の中心線（1＇軸）と(1)軸（B 構面の 外面）のずれをみると、煉瓦小口幅 2 枚分と絽目地幅の 1.5 倍分の 和である(図ー3)。計画時の目地割のディテールにおいて、棟瓦小口 幅を 3 寸 6 分、縦目地幅を 3 分と設定していたと仮定するとこの値 は、

$3.6 \times 2+0.3 \times 1.5=7$ 寸 6 分 5 厘 と計算される(図-3)。そして(2) 軸を(1) 軸と(3)軸の中心位置とするためには次の計算になる。

(56.82-15.66-0.765) $/ 2=20.1975$

これが(2)軸(3)軸間寸法の決定経緯と推測する。

(1)軸(2)軸間は、20.1975+0.765=20.9625 となり、5毛の位まで の書入れ寸法の意味はこのようなものであったと理解される。

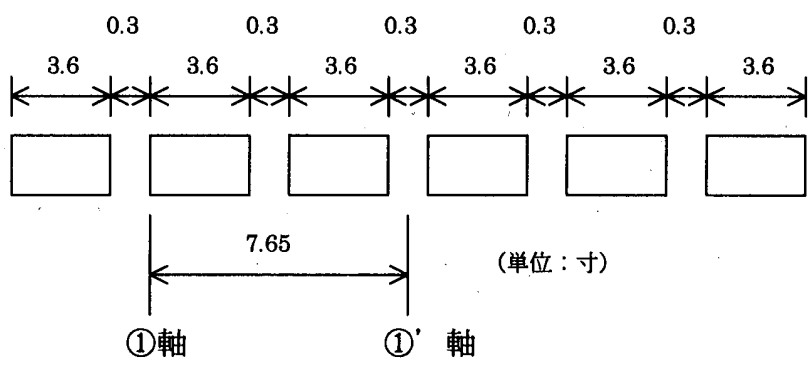

図-3 A 構面左端柱型の目地割模式図

\section{5. 実現された煉瓦壁体の構工法と寸法体系}

娻瓦外壁の積み方は、小口積みあるいはドイツ積みと称されるも のであり、基本的に棟瓦小口面のみを外装に表す意匠である。しか しこれは構造体の積み方を表しているのでは無く、いわゆる表積み 化栍棟瓦であり、構造体（裏積み）の積み方はイギリス積みである ことは建物内側から壁面を観察すれば分かる。娻瓦、目地幅および 棟瓦モデュール寸法の実測調查注 9) は、内装面については 2002 年 2 月 1 日、外装面の表積み化精棟瓦については 2003 年 5 月 28 日と 6 月 5 日に実施した。

内装面の調查結果は表ー 1 および表－2 である。これによると水 平方向には長手 5 枚分＝小口 10 枚分（20Uh）がそれぞれ 39 寸に 納まっている。鉛直方向は 4 段分が 9 寸に納まっている。従ってモ デュール寸法は、長手モデュール（4Uh）が 7 寸 8 分、小ロモデュ 一ル (2Uh) が 3 寸 9 分、鉛直モデュール（Uv）が 2 寸 2 分 5 厘 である。これはちょうど、煉瓦は東京形、綎目地は 3 分、横目地は 2 分 5 厘の組み合わせの場合と同じモデュールである。ただし実測 值は、棟瓦は東京形よりやや小さく、目地幅は上記よりやや大きい 值を示す傾向が锶察された。なお、蒸米放冷室の間仕切煉瓦壁に穿 たれた小開口の下面に娻瓦の平面が露出しておりここに長円の中に 「製免敷上」の文字の刻印が確認された(写真一2)。これにより、埼 玉県深谷市大字上敷免の日本娻瓦製造株式会社の製品が使用された ことが分かる。

外装面の表積み化粧棟瓦の構工法は、 $\mathrm{E}$ 構面の一部破損部と $\mathrm{N}$ 構 面中央の柱型にある綐槲位置の破損部（写真-3）の観察から孔空 きの「四分の一形 (二五分)」などを用いていることが分かる。日本 棟瓦製造侏式会社の会社概覧に揭載されている図壮10（図-4）のよ うに構築されているものと考えられる。

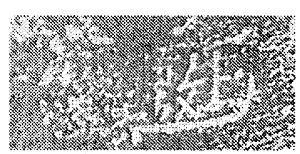

写真-2「製免敏上」の刻印

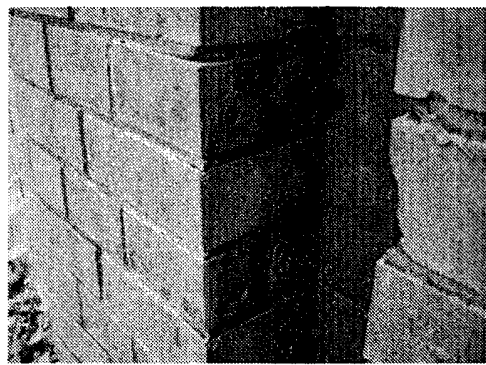

写真-3 N 楧面破損部の钼宗

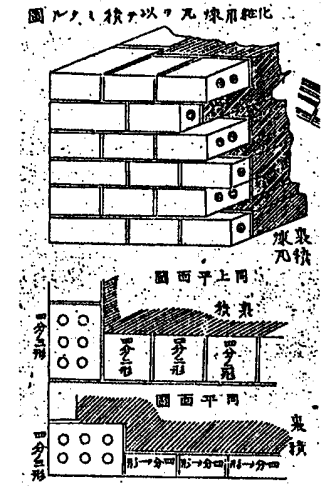

图 -4 表積み化粗 棟瓦の稫み方

表一1 酒類酷造工場内装面の煉瓦寸法およひ目地幅の実測值 括弧内は実测数量

\begin{tabular}{|c|c|c|c|c|c|c|c|c|c|c|c|c|c|c|c|}
\hline & \multirow{2}{*}{\multicolumn{4}{|c|}{$\begin{array}{c}\text { 長手市 L } \\
\text { (33) }\end{array}$}} & \multirow{2}{*}{\multicolumn{4}{|c|}{$\underset{(69)}{\text { 小口巾 }} \mathrm{W}$}} & \multirow{2}{*}{\multicolumn{4}{|c|}{$\begin{array}{c}\text { 高さ } \mathrm{H} \\
(72)\end{array}$}} & \multicolumn{3}{|c|}{ 平均目地幅 } \\
\hline & & & & & & & & & & & & & & & 横 \\
\hline & $\min$ & $\max$ & $\bmod$ & ave & $\min$ & $\max$ & mod & ave & $\min$ & $\max$ & $\bmod$ & ave & 長 & 小 & \\
\hline m m & 222 & 226 & 224 & 224.2 & 104 & 110 & 107 & 107.3 & 56 & 60 & 59 & 58.2 & 11.48 & $10.72^{\circ}$ & 10.15 \\
\hline 寸 & 7.33 & 7.46 & 7.39 & 7.40 & 3.43 & 3.63 & 3.53 & 3.54 & 1.85 & 1.98 & 1.95 & 1.92 & 0.38 & 0.35 & 0.34 \\
\hline
\end{tabular}

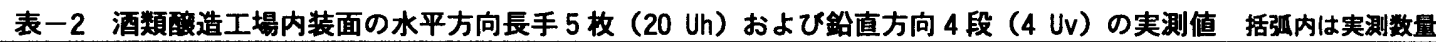

\begin{tabular}{|c|c|c|c|c|c|c|c|c|c|c|c|c|}
\hline & \multicolumn{4}{|c|}{ 長手コース:20Uh（13） } & \multicolumn{4}{|c|}{ 小ロコース：20Uh（27） } & \multicolumn{4}{|c|}{ 鉛直方向：4Uv（41） } \\
\hline & $\min$ & $\max$ & $\bmod$ & ave & $\min$ & $\max$ & $\bmod$ & ave & $\min$ & $\max$ & $\bmod$ & ave \\
\hline min & 1176 & 1183 & 1179 & 1180.5 & 1175 & 1190 & 1181 & 1181.5 & 269 & 279 & 274 & 273.6 \\
\hline 寸 & 38.81 & 39.04 & 38.91 & 38.96 & 38.78 & 39.27 & 38.98 & 38.99 & $\begin{array}{ll}8.88 \\
\end{array}$ & 9.21 & 9.04 & 9.03 \\
\hline
\end{tabular}


現場で採取した孔空き四分の一形化粧棟瓦は、幅 $\times$ 高さ $\times$ 奥行は $107 \times 59 \times 53 \mathrm{~mm}$ では直径 $17 \mathrm{~mm}$ 、表面とその裏側の面以外の 4 面 にちりめん状のあとが観察される。この 4 面をピアノ線で切断して 成形したものと考えられる。

各構面の略平面図への書入れ寸法とその部位の実測可能な面につ いての実測值を表-3に示す。C、E、I の各構面に值の差が出てい るが、これは設計変更により設計寸法が変えられたものとみて誤差 とはしない。それ以外の構面についてみれば極めて高い施工精度で あるということがいえる。

$\mathrm{A}$ 構面でみれば、(1)軸(4)軸間寸法は書入れの值と実測值の差異は

表一3 書入れ寸法と実測値の比較

\begin{tabular}{|c|r|r|r|r|}
\hline 構面 & $\begin{array}{c}\text { 書入れ寸法 } \\
\text { (尺) }\end{array}$ & $\begin{array}{r}\text { ミリ換算 } \\
(\mathrm{mm}) \mathrm{P}\end{array}$ & \multicolumn{1}{|c|}{$\begin{array}{c}\text { 実測值 } \\
\text { (mm) } \mathrm{Q}\end{array}$} & $\mathrm{Q} / \mathrm{P}$ \\
\hline $\mathrm{A}$ & 56.82 & 17,216 & 17,209 & 0.9996 \\
\hline $\mathrm{B}$ & 61.38 & 18,598 & 18,600 & 1.0001 \\
\hline $\mathrm{C}$ & 6.5 & 1,970 & 2,105 & 1.0685 \\
\hline $\mathrm{D}$ & 12.64 & 3,830 & 3,839 & 1.0023 \\
\hline $\mathrm{E}$ & 31.51 & 9,548 & 9,422 & 0.9868 \\
\hline $\mathrm{F}$ & 44.97 & 13,626 & 13,625 & 0.9999 \\
\hline $\mathrm{H}$ & 7.34 & 2,224 & 2,242 & 1.0081 \\
\hline $\mathrm{I}$ & 12.45 & 3,772 & 3,490 & 0.9253 \\
\hline $\mathrm{J}$ & 93.50 & 28,331 & 28,342 & 1.0004 \\
\hline $\mathrm{K}$ & $=\mathrm{M}(11.8)$ & 3,575 & 3,571 & 0.9989 \\
\hline $\mathrm{L}$ & 11.62 & 3,521 & 3,517 & 0.9989 \\
\hline $\mathrm{M}$ & 11.8 & 3,575 & 3,565 & 0.9972 \\
\hline $\mathrm{N}$ & 50.90 & 15,428 & 15,424 & 0.9997 \\
\hline
\end{tabular}

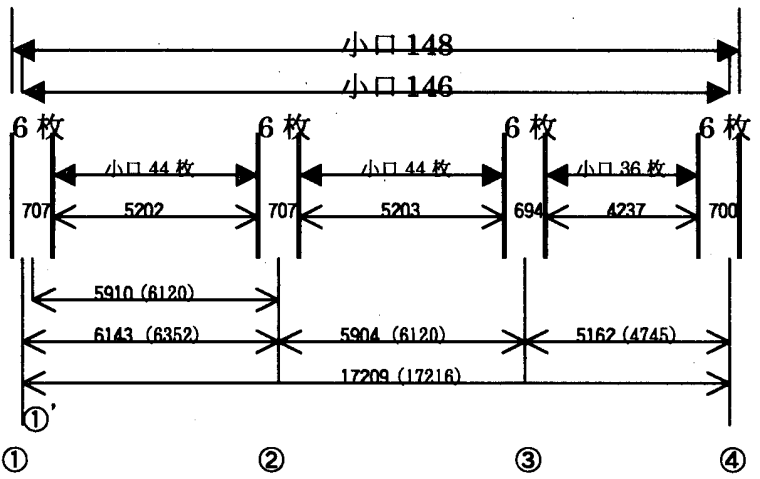

図-5 A 構面目地割の模式図

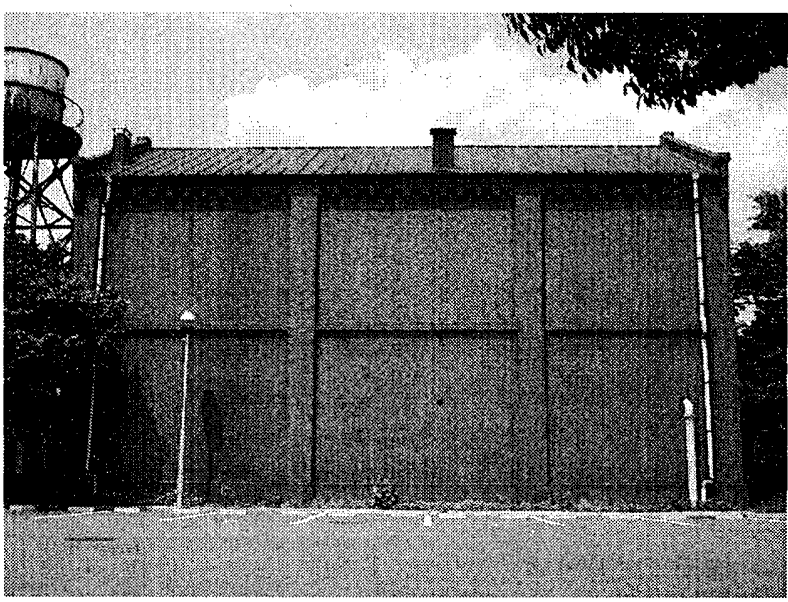

写真-4 A 構面（東面）
$7 \mathrm{~mm}$ で誤差の率は 0.04\%である。

$\mathrm{A}$ 構面は前節でみたように設計寸法の計画時には精妙な計算を行 っていたが、組積造の施工にあたっては目地割と娻瓦モデュールに 十分な配虑が求められる。A 構面は無開口の壁であり（写真-4）、 組積パターンとしては最も単純で基本的な構工法が見られると考え られるので特に取上げ詳細な考察を加える。

四-5 は、A 構面の模式図であり、実測の結果である目地割と実 測寸法が記入されている（括弧内の值は図面書入れ寸法のミリ換算 值)。これによると明らかに(2)軸と(3)軸の柱型の位置が設計変更され ている。(3)軸の柱型は A 構面に直交する間仕切煉瓦壁の受けとして 計画されていたと考えられるが、実際は間仕切壁は図面の位置と変 わらず、柱型だけが移動している。従って、柱型の位直の変更には 構造的な意味は薄く、目地割に関連した意匠面の意味が考えられる。

$\mathrm{A}$ 構面の軒にはロンバルド帯が施されている（写真-4)。 $\mathrm{A}$ 構面 に限らず 2 階の軒には全てロンバルド帯が色々なデザインで施され ており（写真一1）、ロマネスク様式を表現している。ロンバルド帯 は構面の面外方向に娻瓦積みを凹凸させてっくっている。見付け幅 は凹部も凸部も小口 2 枚幅である（図一6）。柱型に挟まれた壁面の 目地割は $44: 44: 36$ (以下、3 スパンの値という) となっており（図 -5)、これらの値は全て 4 の倍数である。この場合、眓一6の「現 状の納まり」のロンバルド帯と柱頭のデザインに納めることができ る。目地割を仮に、偑数ではあるが 4 の倍数ではない值（例えば 38 とか 42）とすると図-6の「4の倍数ではない偶数值の場合」イ、 ロのように納めることができる。しかしこの場合、3 スパンの值が 全て「4 の倍数ではない偶数值」でないと柱頭の納まりに乱れが生 じる。3 スパンの值の和が 124 であり 4 の倍数であるため、現状の ロンバルド帯の納まりとするために現状の目地割が決定されたのは 意匠的に必然性があると考えられる。
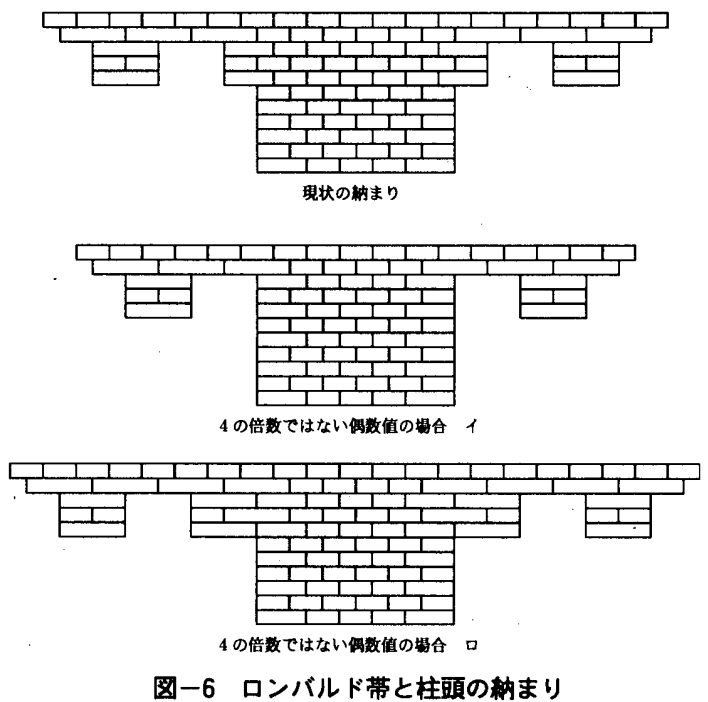

次にモデュールについてみると、前節で示したように設計の段階 では小ロモデュール（2Uh）が 3.9 寸、縦目地幅が 0.3 寸で計画さ れているので、(1)軸(4)軸間の寸法をこのモデュールで追っていくと、 $3.9 \times 146-0.3=569.1$ 寸

となり、図面書入れ寸法の 568.2 寸と 0.9 寸のくい違いが生じてい る。このくい違いの原因は、書入れ寸法の根拠が、前節で指摘した 
表-4 (1)軸(2)軸間の煉瓦、目地およひ部材長寸法 括弧内は実測数量

\begin{tabular}{|c|c|c|c|c|c|c|c|c|c|c|c|c|c|}
\hline & \multicolumn{2}{|c|}{ 小口幅 } & \multicolumn{2}{|c|}{$N(44)$} & \multirow{2}{*}{$\begin{array}{c}\text { 平均維目 } \\
\text { 地相 }\end{array}$} & \multicolumn{4}{|c|}{$20 \mathrm{Uh}(70)$} & \multicolumn{4}{|c|}{$16 \mathrm{Uh}(74)$} \\
\hline & $\min$ & $\max$ & mod & ave & & $\min$ & $\max$ & $\bmod$ & ave & $\min$ & $\max$ & $\bmod$ & ave \\
\hline $\mathrm{mm}$ & 106 & 111 & 109 & 108.7 & 9.29 & 1168 & 1190 & 1180 & 1179.7 & 932 & 955 & 945 & 943.7 \\
\hline 寸 & 3.50 & 3.66 & 3.60 & 3.59 & 0.31 & 38.54 & 39.27 & 38.94 & 38.94 & 30.76 & 31.52 & 31.18 & 31.15 \\
\hline
\end{tabular}

表－5 (2)軸(3)軸間の煉瓦、目地およひ部材長寸法括弧内は実湖数量

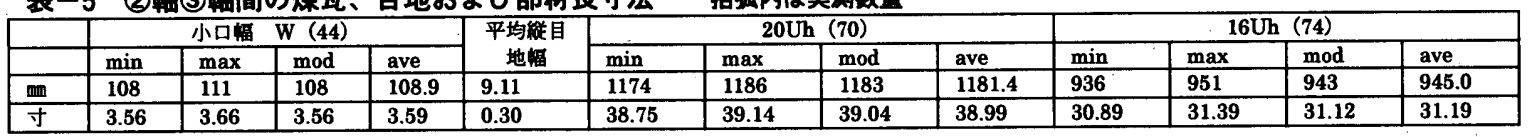

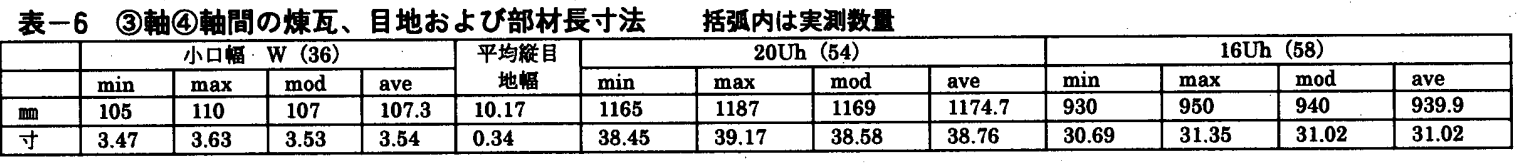

ように、棟瓦壁厚についてはモデュールを考虑した值であるのに対 して、室や廊下の内法寸法は必ずしも煉瓦モデュールを考㦄したも のでなく、37.5 尺とか 12 尺といった空間設計上の必要な值の総計 であったためである。ここに生じた值のくい違いは全長約 $17 \mathrm{~m}$ のう ち $27 \mathrm{~mm}$ 程度のものであり、施工時に吸収可能な值と考えられる。 しかし一方で妻木の工事監理、監督は単格を極めたという逸話があ り、「三分か四分の狂いの為に折角出来上がった蛇腹をば、惜しげも 無く延長五間も十間も取壞させ」11)てやり直させることもあったと いい、0.9 寸（=9 分）の扱いについて施工上の技法があった可能性

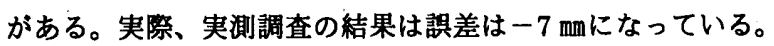

(1)軸(2)軸間、(2)軸(3)軸間、(3)軸(4)軸間それぞれの壁面（柱型の部 分を除く）の煉瓦寸法、縦目地幅寸法および部材長の実測結果を表 4〜6に示す。

20Uh の部材長、つまり小ロモデュール 10 枚分を平均值ベースで みると、(1)軸(2)軸間と(2)軸(3)軸間ではそれぞれ 38.94 寸、38.99 寸 であり 39 寸で施工計画されていたと判断される。つまり小ロモデ ュール (2Uh) は 3.9 寸であり計画上のモデュールと一致している。 しかし(3)軸(4)軸間では 20Uh の部材長は 38.76 寸で誤差が大きく、 小ロモデュール（2Uh）を 3.9 寸とした施工計画ではないと考えら れる。むしろ 16Uh の部材長、つまり小ロモデュール 8 枚分を 31 寸に納めていたとみられる。この場合小ロモデュール（2Uh）は 3.875 寸という精妙なものになる。

ここで(1)軸(4)軸間の寸法を棟瓦モデュールの修正值を考虑して再 計算する。4 本の柱型については仮に小口モデュール 3.9 寸とおき、 (3)軸(4)軸間の柱型に挟まれた壁のみ小ロモデュール 3.875 寸とする と、

左端柱型の(1)軸から柱型端部ならびに右端柱型の(4)軸から柱型 端部

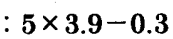

(2)軸柱型および(3)柱型の幅

: $6 \times 3.9-0.3$

(1)軸柱型と(2)軸柱型ならびに(2)軸柱型と (3)軸柱型に挟まれた壁 部

(3)軸柱型と(4)軸柱型に挟まれた壁部 $44 \times 3.9+0.3$

これらを総計すると、

$2(5 \times 3.9-0.3)+2(6 \times 3.9-0.3)+2(44 \times 3.9+0.3)+(36$ $\times 3.875+0.3)=568.2$ 寸 となり 0.9 寸のくい違いを吸収して、 書入れ寸法に一致させることができる。
(3)軸(4)軸間において小ロモデュールを 0.025 寸減じる方法は、実 測值から判断すると（表 4〜6）、樅目地幅で調整するのではなく、 娻瓦の幅で調整しているようである。目地幅は逆に大きい。

ところで、小ロモデュールを 3.875 寸とするといった精妙な作業 が施工現場で実現可能であったかどうかという疑問があるが、これ については、部材長の考察で指摘したように棟瓦 8 枚を水平に積ん で 31 寸とする、といった施工管理をすれば容易に達成できるので 問題はないと考えられる。一方、娻瓦寸法を微妙に小さく（2 厘 5 毛=0.75 mmの減）製造することについては、焼き物の性格上おそら くそれは不可能であると考えられる生 11)。棟瓦はねらいの寸法から ある程度のばらつきが生じることは不可避のことであったとされて いる注 12 )。推測される施工現場における手立てとしては、煉瓦の受 入検査の際、小さめのものを集合して置きそれを(3)軸(4)軸間の施工 分のために準備しておいた、ということは考えられる。

\section{6. まとめ}

旧醇造試験所酒類醇造工場の計画時において、設計寸法の決定に あたり棟瓦モデュールが考虑されたのは壁厚であり、図面に書入れ られた堲厚の值の分析からここでは東京形の煉瓦と緃目地幅 0.3 寸 を想定した設計が行われていたことを示した。しかし室の内法寸法 の决定にあたっては煉瓦モデュールは考虑されていない。したがっ て、書入れられたスパンの寸法の值は、「分」の位まで記述されてい るにもかかわらず煉瓦モデュールに則った值にはならない。また 「毛」の位の值まで図面に書入れる根拠は柱型の目地割のディテー ルを、やはり上記の東京形の煉瓦と繸目地幅 0.3 寸を想定した計画 にあることを示した。壁厚と柱型の精妙な目地割と棟瓦モデュール に対する考虑に対して、室の内法寸法決定時における棟瓦モデュー ルの無視については均衡を失しているように思われる。室の内法寸 法決定要因が室の使い勝手あるいは設置される機器類の寸法による ものかどうかは現在のところ判然としない住 13)。一般に、同時期の 棟瓦造建築の図面書入れ寸法は「分」の位まで記述されている例は 少ない生 14)。本施設の特殊な事情があるのかあるいは妻木頼黄の設 計手法に係るものなのかは分からない。

一方で現実の施工にあたっては目地割と娻瓦モデュールは入念 に検討されなければならない。問題はこの検討行為がどの主体の行 為なのかは建築生産技術上の重要な問題点である。本稿ではその点 
に踏み込んだ考察には及んでいない。今後の研究課題としてここに 提示しておく。しかし、壁面の目地割や、本施設の場合のような口 ンバルド帯の納まり、といった建築意匠に関わる点であるので、建 築家の一義的な関わりがあったことは推測される。

本稿で詳細な検討の対象としたのは無開口の 2 階高の壁面である が、ここでは全長長さの寸法は計画時の值（図面書入れ寸法）を道 守する施工上の技法の存在が見られた。柱型によって三つのスパン に分節された壁面の実測調查の結果、二つのスパンについては計画 上の煉瓦モデュールで施工されているが、ひとつのスパンにおいて、 棟瓦モデュールを変化させ調整する技法が見られた。全長約 $17 \mathrm{~m}$ の うちわずか約 $27 \mathrm{~mm}$ （=0.9 寸）の吸収のため、ひとつの構面におけ る、そのような精妙な技法が存在したかどうかについてはまったく の疑問無しとはしないが、実測調査の結果はそのような技法住 15）の 存在を示している。

我が国においては、煉瓦造建築物の生産が行われたのはおおむね 幕末から大正期のわずか半世紀強にすぎない。その間、西洋技術の 受容過程において先人が心血注いで工夫した技法についてまだ解明 されていないものが多いと思われる。本稿の指摘は、施工現場にお ける極めて精妙な技法と娻瓦造構工法における寸法調整機能の柔軟 性の一端を解明したものに過ぎない。まだその他、文献調査のみで は解明不能な優れた技法、技能の存在があると考えられる。建築生 産技術史の研究の目的は一義的には建築技術史上の真実を明らかに することであるが、それとともに今後の我が国における新構工法開 発における有益な情報を提供するのものであると考えられる。

\section{钎辞}

本稿をまとめるための文献調査、現地調査にあたって、独立行政 法人酒類総合研究所にご協力をいただいた。ここに深甚の意を込め て謝礼申す次第である。

注郍

1) 2001 年 4 月に機構改革により独立行政法人酒類総合研究所となり、主た る事務所は広島県東広島市にある。東京事務所には酒類情報室、技術指 道室があり、住所は東京都北区潼野川 2-6・30である。

2) 「日本近代建築総覧（日本建築学会）1980.3」には記載がない。「妻木賴 黄と臨時建築局（編集博物館明治村、発行名古屋鉄道株式会社）1990.10 では、本施設に関する資料の写真紹介と妻木年譜に本施設が記述されて いる。また 1989 年に当時近畿大学九州工学部建築学科の山口昭三助教授 が調查されている。

3）明治三十七年五月九日栜令第一三六号

4）宮崎善吉の落札を示す直接的な文書は残されていないが、明治 36 年 (1903)5 月 9 日付け「醇造試験所新築工事変更調書」および明治 36 年 (1903)月日不明「醇造試験所新筑工事設計一部仕様変更申請書」の記名 が神田区三河町二丁目十九番地、宮崎善吉になっていることから落札者 と判断した。なお、宮崎善吉の名は、「大藏省臨時建築部年報」には淀桥 煙草製造所および浅草煙草製造所（ともに明治 44 年度竣工、娻瓦造）の 労力供給請負人、部分的な請負人のひとりとして記録されている。

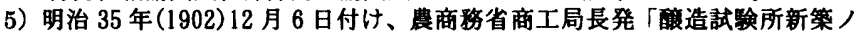
件」に添付された「醇造試倹所工場新築工事功程表」に二月一日着工、 最後の跡揥除の終期が十一月七日になっている。また明治 36 年(1903) 5 月 22 日付け、農商務省会計課長発「酸造試験所新築工事仕様変更及期限 延期等の件」に「設計変更ノ為入竣功期ヨリ三十六年十一月三十日迄二 十三日間延長致度見込二有」の記述がある。

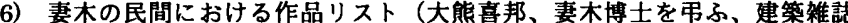
第 359 号、p6、1916.11）には日本麦酒株式会社、丸三ビール会社半田 工場、大阪朝日ビール会社工場が記載されている。また同じ号の小林金 平の「妻木博士の事共」には、「博士はビール醇造所の建築に造詣が深か つた。独逸のビールの本場に居られ、自分む大好物であった為めか， の工場建築に詳しく、各会社に侬頼されて、自ら其の仕事に当たられた とある。從ってここで「独国麦酒酸造会社ノ建築法」に関して、妻木か 係った可能性は大きいと考元られる。

7）「日本赤十字社旧家屋建築記録（日本赤十字社）1978.2」,p85 に揭載。 解説によると妻木頼黄の御令孫妻木良郎氏の提供された妻木の履歴書類
12 点のうちのひとつである。

8）目地幅に言及した建築技術書として以下がある。括弧内数値は記述され ている目地幅寸法である。中村達太郎「建築學階梯巻之上」p42 中村順 三郎; 初版明治 21 年/1888 年 (2 分 5 厘乃至 3 分)、朝合清一「建勧設計 通書」p79 共益商店書店; 初版明治 30 年/1897 年 (2 分 5 厘乃至 3 分)、 大泉龍之輔「建築工事設計便臨全」建築書院 p74;初版明治 30 年/1897 年 (2 分乃至 3 分)、三橋四郎「和洋改良大建筑學上巻」p89大合害店;泑版

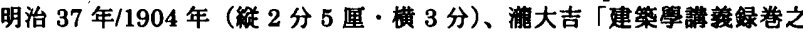
声」p161 建築書院;初版明治 38 年/1905 年 (2 分乃至 3 分)、小國已一「建 筑工事仕様便覧全」建築畫院 $\mathrm{p70}$; 初版明治 38 年/1905 年（維 3 分・横 2 分 5 厘)、田中豊太郎「和洋建筑設計宽例上」建筑書院 p118;初版明治 38 年/1905 年 (2 分 5 厘)、井上䋈次郎「建築師要筧」p356 博文館; 初版明 治 43 年 $/ 1910$ 年 (3 分)、建筑世界社「最新家屋建勧設計便臨」p47 須原 屋害店; 初版明治 43 年/1910 年 (2 分 5 厘乃至 3 分)、㚼中键三「土木建 築工事埥負便覧」p70 大倉書店; 初版大正 3 年/1914 年 (2 分)、河津七 郎·吉田全三「建築工事仕様見積」大日本工業学会 $\mathrm{p58}$; 初版大正 4 年/1915 年 (繸 3 分・横 2 分 5 厘)。仕様書例として以下がある。辰野金吾・暮西 萬司「家屋建築実例壱巻」p68 須原屋書店; 初版明治 41 年/1908 年 $(2$ 分 5 厘)、早稚田大学理工科建築科「建築工事実施例 I 」 非克品; 大正 2 年/1913 年 (2 分 5 厘)。

9）実娜調查の方法、記号の意味等については、「長谷川直司・馬場明生・守 明子・渡部鹖道・静村貴文・河原利江：明治・大正期における㷄瓦造建 築物のモデュールに閣する研究（その2）旧山口県庁および県会議事堂 における部材寸法調查およびモデュール，日本建筑学会大会（東北）学 術講演梗概集 F-2 分冊，pp.51·52，2000.9」の報告と同様である。娻瓦 寸法と目地幅寸法の組合せを娻瓦モデュールと呼び、水平方向では長手 モデュールの 1/4、小ロモデュールの $1 / 2$ を単位モデュール（ユニットモ デュールともいう）といい，記昂はUh とする。鈶直方向は㜛瓦の厚み と横目地幅一本の和が単位モデュールであり、記号はUvとする。

10）契井恒平著「煉瓦要説」(明治 35 年/1902 年 8 月刊行) の附録「会社概

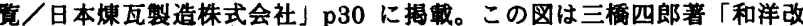
良大建築學上巻」(明治 37 年/1904 年 2 月刊行)および大熊喜邦・小島栄 吉・大口清吉・横山信著「改訂增補大建築学第壱巻」(大正 12 年/1923

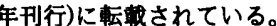

11）端面処理の二次加工を行えば必ずしも不可能ではないが、現場で採取し た小さめの孔空き「四分の一形」煉瓦の端面はちりめん状となっており 二次加工はなされていない。

12）「和洋改良大建築學上巻」p97に「煉瓦八焼化シテ些造スルモノナレバ

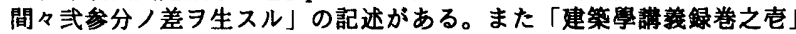
p135にも「同じ製造所にて造りたる品にても火の利きたる品と赎けの 足らぬ品とでは同じく寸法に相異を生ずるものにして七寸五分の管の ものが七寸二三分位に出来たるものもあれば七寸七分位の大きなもの もあるものなれば此遭は能く御承知ありたし」の記述がある。

13）「アサヒビール株式会社吹田工場創業時のビール酸造工場建物に関す 了学術調查報告書、金田潔、西摆英和著、建筑研究協会、1990.10)(pp108 -109）によると、明治 24 年(1891)竣工のこのビール工場建筑で妻木 は実施設計（翻訳設計）を行ったが、元図はドイツのゲルマニア機械製 作所が作成したメートル法で描かれた四であり、鉛直方向の寸法におい てメートル法と尺寸法を調整した可能性を指摘している。

14）「図面でみる都市建策の明治、鈴木博之・初田亭編集、柏書房、1990.4」 に所收された建筑物のうち棟瓦造でかつ、本施設の図面のように寸法が 記入されていると確証されるものは以下の 20 件がある。造幣寮地金局 (明治 16 年 $/ 1883$ 年)、大藏省専売局 (明治 42 年/1909 年)、ドイッ 公使館 (明治 30 年 $/ 1897$ 年)、上海総領事館 (明治 44 年 $/ 1911$ 年)、 吉林領事館（明治 43 年 $/ 1910$ 年）、作世保市役所（明治 43 年頃 $/ 1910$ 年)、干葉県庁（明治 45 年 $/ 1912$ 年）、日本銀行門司西部支店（明治 31 年 $/ 1898$ 年)、第一銀行京都支店 (明治 39 年/1906 年)、村井銀行京都 支店（大正 1 年頃 $/ 1912$ 年）、東京火炎保险（明治 38 年 $/ 1905$ 年）、帝 国生命保險大阪支店（明治 40 年 $/ 1907$ 年）、万世橋停車場（明治 44 年 $/ 1911$ 年)、日本赤十字本社 (大正 1 年/1912 年)、東京帝国大学医科 大学病理学研究室 (明治 36 年 $/ 1903$ 年)、東京復活大聖堂 (明治 24 年 /1891 年)、日本㕷公会教会掌 (明治 40 年 $/ 1907$ 年)、日本メソジスト 銀座教会堂 (明治 45 年/1912 年)、大阪図書館 (明治 37 年/1904 年)。 これらのうち、書入れ寸法が「分」の位まで記述されているのは下線を 付けた 5 件である。

15）「長谷川直司他；明治・大正期における娻瓦造建筑物のモデュールに閶 する研究（その 4) 西谷净水場旧整水室の媡瓦壁ボンディングパターン の特徽。日本建築学会大会 (北陸) 学術講演梗概集 F-2 分冊, pp.319-320, 2002.8」において、直交する構面において異なる媡瓦モデュールで実現 された事例の存在を示した。

参考文献

1)「西造試験所㳂革誌」、酸造試踰所、pp1-82、1929.5.9

2）「醇造試験所七十年史小、国䂱庁醇造試験所、pp1-9、1974.5.9

3) 文献 1)p72

4) 文献 2)pp29-32

5) 文献 1)pp11·15

6) 文献 1)p19

7）大能喜邦：妻木博士を年ふ、建筑雑誌 No.359、pp.1-2、1916.11

8)「職員録」明治 35 年甲、明治 36 年甲

9）諸井恒平著「娻瓦要説」、博文館、p39、1903.9.15

10) 大高生右衛門：娻瓦の形状に就いて、建築雑誌 No.225、pp.63.66、1905.9 11）矢橋賢吉；妻木博士を憶ふ、建築隻誌 No.359、pp.14-18、1916.11

(2003年 7 月 8 日原稿受理， 2003 年 9 月 19 日採用決定 